University of South Carolina

Scholar Commons

$5-1994$

\title{
A Reappraisal of Diversification in the Federal Courts: Gender Effects in the Courts of Appeals
}

Donald R. Songer

University of South Carolina - Columbia, dsonger@sc.edu

Sue Davis

University of Delaware

Susan Haire

University of North Carolina at Greensboro

Follow this and additional works at: https://scholarcommons.sc.edu/poli_facpub

Part of the Law Commons, and the Political Science Commons

Publication Info

Published in Journal of Politics, Volume 56, Issue 2, 1994, pages 425-439.

http://www.journalofpolitics.org/

(C) 1994 by Cambridge University Press for the Southern Political Science Association

This Article is brought to you by the Political Science, Department of at Scholar Commons. It has been accepted for inclusion in Faculty Publications by an authorized administrator of Scholar Commons. For more information, please contact digres@mailbox.sc.edu. 


\title{
A Reappraisal of Diversification in the Federal Courts: Gender Effects in the Courts of Appeals
}

\author{
Donald R. Songer \\ University of South Carolina \\ Sue Davis \\ University of Delaware \\ Susan Haire \\ University of North Carolina at Greensboro
}

Prior scholarship on the effect of the increasing number of female judges leads to three contrasting sets of expectations. Early writings and views of affirmative-action activists suggested that female judges would be more liberal than male judges. On the other hand, a series of empirical studies suggest that we should expect no gender differences. In contrast to both of these perspectives, several feminist scholars suggest that women will be more liberal only when that position expresses support for full participation in the community. These contrasting expectations were tested by analyzing the votes of appeals court decisions in three issue areas. No differences were discovered between male and female judges in obscenity or criminal search and seizure cases. However, in employment discrimination cases, female judges were significantly more liberal than their male colleagues.

\section{INTRODUCTION}

nly eight women had served as federal judges before 1977 when President Jimmy Carter instituted a plan to diversify the federal courts. ${ }^{1}$ Carter's reforms resulted in the appointment of 11 women to the United States Courts of Appeals and 29 to the federal district courts. Subsequently, Presidents Ronald Reagan and George Bush appointed a total of six women to the Courts of Appeals. ${ }^{2}$ Although the number of women on the federal intermediate appellate bench remains relatively small, that number is large enough to make it possible, indeed, essential to begin to study their decision making. In the present study we analyze the behavior of judges on the United States Courts of Appeals to discover whether differences in voting behavior may be attributed to the gender of the judge.

\footnotetext{
${ }^{1}$ See Berkson and Carbon (1980). See Martin $(1982,1987)$. For documentation of the underrepresentation of women on the bench, see Cook (1988).

${ }^{2}$ Ronald Reagan appointed four women and George Bush had appointed two as of August 1990.
}

The Journal of Politics, Vol. 56, No. 2, May 1994, Pp. 425-39

(C) 1994 by the University of Texas Press, P.O. Box 7819, Austin, TX 78713-7819 


\section{Previous Studies Comparing Male and Female Decision Makers}

Advocates of diversification of the federal bench hoped that increasing the number of women would not only give qualified women professional opportunities that had long been denied to them but would also enhance the legitimacy of the judiciary insofar as the courts would begin more accurately to reflect the composition of the general population. Many supporters of Carter's efforts to increase the number of women on the federal courts also hoped that women judges would actually represent women's interests. One scholar, for example, explained that, "The organized campaign to place more women on the bench rests on the hope that women judges will seize decision-making opportunities to liberate other women" (Cook 1981, 216). Critics of Carter's selection reforms, including his two successors, expressed disdain for the liberal activism of the Carter appointees and contended that they were not of the same high caliber as the judges who were selected during Reagan's presidency (Cohodas 1983, 83).

Initially, a number of social scientists shared the general expectation that women on the federal bench would help to produce liberal decisions. Kritzer and Ulhman (1977), for example, wrote that, "Common sense as well as sociological theory suggests that the socialization experiences of men and women are significantly different" (86). Those differences, combined with cultural norms, they argued, should lead to differences in judicial behavior. Goldman (1979) suggested that affirmativeaction appointments could be expected to bring a heightened sensitivity to judicial resolution of questions of race and sex discrimination. ${ }^{3}$

Empirical studies of differences in patterns of decision making among political elites other than judges provide only weak support for the initial expectations regarding female judges. Leader's (1977) examination of interest group ratings of members of Congress led her to conclude that women were more liberal than men, particularly in the areas of social welfare and defense spending. ${ }^{4}$ Welch (1985), who analyzed Conservative Coalition scores, found that women were more likely than men to cast liberal votes, but that the differences had decreased over time. In contrast, studies of the views of political party elites (Constantini and Craik 1972) and civil servants (Thompson 1978) failed to reveal significant differences based on the sex of the decision maker. Thomas (1987) found that women legislators in California were no more liberal than their male counterparts while Thomas and Welch (1991) concluded that women legislators in 12 states were only slightly more likely than men to give higher priority to women's issues than to business and commerce.

To date, systematic analyses of judicial behavior have failed to provide much more support for the contention that women judges will differ from their male

\footnotetext{
${ }^{3}$ Additionally, Martin (1982) predicted that the women appointed by Carter would help create a more liberal judicial policy toward women.

${ }^{4} \mathrm{~A}$ factor analysis of congressional voting from 1961 to 1975 led Frankovic (1977) to similar conclusions.
} 
counterparts than the studies of other political elites. For example, two studies of the sentencing patterns of urban trial court judges revealed no significant differences between males and females (Kritzer and Uhlman 1977; Gruhl, Spohn, and Welch 1981). The results of those studies, however, may not be generalizable to the quite different context of decision-making by federal appellate judges. Still, two studies of voting behavior on the United States Courts of Appeals revealed only slight differences between men and women judges (Gottschall 1983; Davis 1986). In contrast Allen and Wall (1987), who examined the votes of judges on four state supreme courts, found that four of the five women voted on "women's issues" in a way that placed them at the liberal extreme of their respective courts. While Allen and Wall's (1987) study provides partial support for the expectation that women judges will be more liberal than their male colleagues, it is limited by the small number of women and the small number of cases included in the study ${ }^{5}$ and the absence of controls for the partisan background of the judges.

In the most ambitious attempt to date to determine the effects of women judges, Walker and Barrow (1985) compared the decisions of male and female judges on the federal district courts. Their results in cases involving criminal procedure paralleled those of the earlier sentencing studies: there were no significant differences between men and women judges. Likewise, in cases that involved women's policy issues there were no significant differences. In the area of personal liberties and minority policy issues, however, the differences between male and female judges were statistically significant. Those differences were not in the expected direction-male judges were one and one-half times more likely than female judges to support the liberal position. The results also indicated that female judges were significantly more likely than their male counterparts to defer to positions taken by government. ${ }^{6}$ As the authors noted, "such patterns could not have been predicted from the political rhetoric expressed during the debate over the diversification of the federal bench" (Walker and Barrow 1985, 608).

\section{Feminist Legal Theory}

The existing empirical studies of differences in patterns of decision making between male and female political elites provide very little support for a hypothesis that women judges on the Courts of Appeals will be more liberal than their male counterparts. Still, a number of scholars have theorized that women judges will differ in fundamental ways from their male colleagues. Feminist legal scholars argue that women lawyers and judges will bring a different perspective to the law, employ a different set of methods, and seek different results than the (male) legal tradition would seem to mandate. The well-known work of psychologist Gilligan

\footnotetext{
${ }^{5}$ The number of cases ranged from 10 to 14 cases for each court.

${ }^{6}$ In still another study, Gryski, Main, and Dixon (1986) found only a weak and statistically insignificant relationship between the presence of a female judge and state high court decision making in sex discrimination cases.
} 
(1982) provides some empirical support for the claims that feminist legal theory makes. Gilligan (1982) discovered differences in the ways that males and females understand themselves and their environment, and the way they resolve moral problems. She found that males tend to define themselves through separation, measure themselves against an abstract ideal of perfection, and equate adulthood with autonomy and individual achievement; they conceive morality in hierarchical terms - a ladder. In contrast, females often define themselves through connection with others and activities of care, and perceive morality in terms of a web.

How might the differences that Gilligan (1982) found manifest themselves in judging? Karst (1984) asserted that women's perspective would alter the male conception of freedom that shaped the values of the Constitution. He reasoned that principles of liberty, property, due process, and equality traditionally have represented guarantees of protection from interference by others; they express a desire for separation from government as individual liberties rather than as collective rights. But women judges could transform those principles by integrating such values as connection, caring, and responsibility. Thus, the state could acquire an affirmative duty to ensure that each of its members has the ability to participate fully in the community. Binion (1991, 9) asserted that integrating women's experience into constitutional analysis is likely to result in a reformulation of rights analysis to redefine liberty as more than protection from government and to reconceptualize the nature of community. Sherry (1986) also drew on Gilligan's work to identify characteristics of what she referred to as a feminine jurisprudence. A jurisprudence that emphasizes connection (in contrast to autonomy), context (as opposed to fixed rules), and responsibility (in contrast to rights) would be feminine but, she pointed out, not necessarily feminist. Nor would it necessarily be liberal but would "encompass aspects of personality and relationship to the world that have nothing to do with one's political preferences" (Sherry 1986, 583). According to Sherry (1986), Justice Sandra Day O'Connor's decision making manifests a jurisprudence that differs clearly from that of her male colleagues. O'Connor, in Sherry's assessment, has not been as willing as the other conservatives on the Court to permit violations of the right to full membership in the community. Moreover, she has tended to support individual rights only when they implicate membership in the community. O'Connor's decision making also has reflected a view that shaping the values of the community through governmental processes is an important function of community members (Sherry 1986, 603).

It is important to note that feminist legal theory makes no claim that the differences between men and women judges will emerge simply as liberal or conservative voting patterns across the board. The theory suggests that women judges will be liberal insofar as they will vote to support claimants who allege discrimination that has resulted in exclusion from full participation in the community. In contrast, women judges would be categorized as conservative on the basis of their votes in cases in which individual rights conflict with community interests. 


\section{Methodology and Framemork}

We have formulated three alternative sets of hypotheses based on the predictions of supporters of diversification on the federal bench and social scientists, empirical analyses of voting behavior, and feminist legal theory. First, the initial predictions about women judges led us to hypothesize that they will be more liberal than their male counterparts across the three issue areas that we have included in our analysis: search and seizure, obscenity, and employment discrimination. ${ }^{7}$ Women, the early predictions implied, would be more protective of civil liberties because they are likely to have particular empathy for individuals who are disadvantaged (as women themselves have been) in American society.

In contrast, the empirical studies of voting behavior led us to our second hypothesis: female judges will not be more liberal than their male counterparts in any of the three issues areas. Regardless of the extent to which their early socialization differed from that of their male colleagues, their common socialization into the legal subculture and the partisan and contextual pressures from the democratic subculture which cut across gender lines tend to cancel out any gender-based differences.

Feminist legal theory provides the basis for our third set of hypotheses. Women judges will be more conservative in obscenity cases than their male counterpartsexplicit sexual materials may be viewed as perpetuating the oppression of women and as damaging to the moral fiber of the community. They will be no more likely than their male counterparts to support the liberal position in search and seizure cases - to support the claim of a criminal defendant would conflict with the interests of the community. Finally, women will be more liberal than men in employment discrimination cases as women tend to emphasize rights that are interdependent, such as full membership in the community. Discrimination may be viewed as a problem of exclusion.

The present study takes as its unit of analysis the votes of all regular judges of the United States Courts of Appeals, including those on senior status, from the District of Columbia Circuit and the 11 numbered circuits from 1981 to 1990. We excluded from analysis the votes of judges from other courts who temporarily participated on appeals court panels. The analysis of obscenity cases is based on all opinions published in the Federal Reporter during this period. These opinions contained 239 votes that were suitable for analysis. ${ }^{8}$ Since there were more than 3,000 published opinions in the decade studied for both search and seizure and

\footnotetext{
${ }^{7}$ As noted later, fully specified models of judicial voting behavior require the inclusion of controls for specific case facts and the nature of the particular types of litigants who appear in court. To properly specify such case facts, narrowly defined case types must be chosen for analysis. Previous work has shown that obscenity and search and seizure cases meet this criterion (see Hagle 1991; McGuire 1990; Songer and Haire 1992; Segal 1984).

${ }^{8}$ Cases which had missing data for one or more of the variables were excluded from the logistic regression.
} 
employment discrimination cases, samples of each case type were drawn for analysis. First, for the employment discrimination cases, a search utilizing the WESTLAW electronic data base identified the universe of cases whose decisions were published in the Federal Reporter. From the universe of cases, a random sample of 200 decisions was selected. But since the proportion of votes cast by women judges remains low, such a sample would produce too few votes by women to permit satisfactory analysis. Therefore, the original sample of 200 cases was supplemented by identifying the universe of cases in which each woman judge participated and randomly selecting three additional cases from the universe of participations of each woman (in these three cases selected for each woman, the votes of all judges were coded). For search and seizure cases, a random sample of 40 cases per year which had been drawn for another project was employed. These samples yielded 1,158 votes in search and seizure cases suitable for analysis and 607 votes in employment discrimination cases. ${ }^{9}$

To test our hypotheses, we coded the dependent variable " 1 " for a liberal vote and "0" for a conservative vote. Votes which could not be unambiguously classified as either liberal or conservative (e.g., those to affirm in part and reverse in part) were excluded from analysis. For obscenity cases, we adopted the definition of a "liberal" vote, employed in recent empirical studies of the obscenity decisions of appellate courts (Songer and Haire 1992; Hagle 1991; Dudley 1989). Thus, a vote to support a nonrestrictive position on the use and dissemination of allegedly obscene materials (e.g., overturning an obscenity conviction or concluding that a challenged book was not obscene) is liberal. For search and seizure decisions, we defined a liberal vote as one in favor of holding that a search was unreasonable or that challenged evidence must not be used. ${ }^{10}$ For job discrimination cases, we defined a liberal vote as one which supported the claimant. ${ }^{11}$

In order to assess gender-based effects while controlling for a large number of independent variables we employed logit in a multivariate analysis. Logit, which is preferred to regression when the dependent variable is dichotomous (Aldrich and Nelson 1984), permits the calculation of a maximum-likelihood coefficient for the effect that each independent variable has on the probability that the dependent variable will assume a specified value (in the analysis below, on the probability of a liberal vote).

\footnotetext{
${ }^{9}$ The limitation of the analysis to published opinions means that some caution must be exercised before generalizing from these results to all cases. It would be prohibitively expensive to sample the unpublished decisions of the courts, and we have no way to know for certain whether the effect of gender is the same in published and unpublished decisions. Songer $(1988,1990)$ found that for other indicators of judicial values, the relationship between values and votes was in the same direction in published and unpublished decisions. Therefore, we suspect that the effect of gender would be similar in unpublished decisions, but the magnitude of that effect may be less in unpublished than in published decisions because unpublished decisions are likely to contain fewer opportunities for exercise of judicial discretion.

${ }^{10}$ That is, we adopted the definition employed by Segal (1984) but reversed the order of votes coded as " 1 " and " $0 . "$

"In claims brought by a male challenging an affirmative-action plan, we coded a vote in favor of the male plaintiff as conservative.
} 
We constructed a separate model for each of our three issue areas. A number of studies suggest that judicial values reflected in regional differences and partisan appointment patterns are strongly related to the votes of judges (Tate and Handberg 1991; Songer and Davis 1990; Howard 1981). Therefore, for each model we included a measure of region $(1=$ South, non-South $=0)$ and a variable to represent presidential appointment. The appointment variable was coded " 1 " if the judge was appointed by a "liberal ideology conscious president," " -1 " if appointment by a "conservative ideology conscious president" and " 0 " if appointed by a president who was not ideology conscious. ${ }^{12}$ We also included fact patterns of cases and the nature of the litigants in each model. Recent analyses of both search and seizure decisions of the Supreme Court (Segal 1984) and of the obscenity decisions of a wide spectrum of appellate courts (Songer and Haire 1992; McGuire 1990; Hagle 1989; Dudley 1989) suggest that differences in the fact patterns of cases before appellate courts may explain a substantial portion of the variance in the decisions of the courts and the votes of individual judges. Similarly, recent studies (Songer and Sheehan 1992; Songer and Haire 1992; Wheeler et al. 1987) demonstrate that the nature of the litigants involved in a case affect the likelihood of a liberal vote even after controls are introduced for other case characteristics and the backgrounds of judges. That is, the likelihood that a given judge will support the liberal position may be significantly affected by the specific case characteristics; and this effect may be independent of any gender effects.

To identify the most important case characteristics for obscenity and search and seizure cases, we relied on existing models. For obscenity cases, we selected the case characteristics that Songer and Haire (1992) have found to have the greatest impact on the voting of appeals court judges. Thus, we coded whether the litigant opposing the government was an individual or a bookstore, the nature of the allegedly obscene material, and whether the distribution of the material was restricted to adults. For search and seizure cases, we adapted Segal's (1984) factpattern model, coding case facts relating to the location of the search, the extent of the search, whether there was a warrant or probable cause, and whether or not any of the exceptions to the warrant requirement were present. ${ }^{13}$

\footnotetext{
${ }^{12}$ This classification of presidents is derived from that employed by Tate and Handberg (1991). We coded Carter, who was not included in the Handberg and Tate classification, as a liberal ideologyconscious president.

${ }^{13}$ Segal (1984) defined probable cause and the arrest variables as the proportion of judges below who found that there was probable cause or that the arrest was lawful. Since for our data all cases came from a single judge decision of the district court, the values for these variables could only take on the values " 1 " if the district court found probable cause, etc., or " 0 " if the district found that there was no probable cause. Segal's (1984) exception variable was simply the total number, out of a maximum of six that he coded, of exceptions that were present. While maintaining the basic format of the variable, we coded two additional exceptions that were recognized by the Supreme Court subsequent to the time of Segal's (1984) study; a good faith exception and the inevitable discovery exception. It is unclear from Segal (1984) whether these exceptions were coded as present if the Supreme Court concluded that they were present or the lower courts made such a determination. For our coding, we relied on the determination of the district court (as reported in the appeals court's opinion) as to whether or not a given exception was present.
} 
For employment discrimination cases, we constructed a model based on our analysis of recent opinions of the Supreme Court. We focused on the findings of the trial court in the following areas: evidence at trial of past discrimination, the nature of the alleged discrimination, effect on seniority rights, and the nature of the relief sought. To this fact-pattern model, we added the variables for region and presidential appointment used in the models of search and seizure and obscenity decisions. Finally, to assess the effects of litigant status, we included an indication of whether the plaintiff was identifiably poor and whether the defendant was either a business or a government.

In summary, each of the three models includes identical measures of region, the appointing president of each judge who participated on the panel, and the gender of each judge. The models also contain variables which attempt to tap the most relevant case characteristics for each of the three areas of law investigated. Since statutes and precedents in these three areas are different, the case characteristics included in the three models are necessarily different. As a result, the models are not identical. Due to this use of partially different models for the three issue areas, some caution is necessary when interpreting the relative impact of gender in the three areas. Unfortunately, there appears to be no way around this dilemma. If case facts were omitted from the models in order to produce identical models for each issue area, the models would be seriously underspecified and any relationships discovered between gender and judicial voting decisions might be spurious.

\section{Results}

We examined the impact of gender on judges' behavior separately in each of three categories of cases with controls for case facts as well as region and presidential appointment. The model for judges' votes in obscenity cases is presented in table 1 .

The model does a very good job of predicting the votes of the judges. Overall, the model correctly predicts $86.2 \%$ of the judges' votes in the universe of published obscenity decisions that we examined, a reduction in error of $53.2 \% .{ }^{14}$ Both the presidential appointment variable and region were significant predictors of judges' votes. Additionally, the type of litigant and various case facts proved to be important. However, as table 1 shows, the gender of the judge appears to have no effect on the likelihood of a liberal vote when other factors are taken into account. The coefficient for gender is small and statistically insignificant. Moreover, the addition of gender to the model adds nothing to the predictive power of the model.

\footnotetext{
${ }^{14}$ The reduction-in-error figure is a measure of the improvement in the prediction of the values of the dependent variable that is provided by the model compared to the predictions that would be made by the naive strategy of predicting that the value for every case was the value reflected by the modal value of the dependent variable. It is the proportion of the error made in the naive prediction that is eliminated by the model. A commonly accepted formula for computation of the reduction in error (ROE) is: ROE = 100 ( $\%$ correctly classified $-\%$ in the modal category) $/(100 \%-\%$ in the modal category).
} 
TABLE 1

LOGIT COEFFICIENTS FOR THE LIKELIHOOD OF A LIBERAL VOTE OBSCENITY CASES, 1981-1990

\begin{tabular}{lrl}
\hline Independent Variables & MLE & SE \\
\hline Intercept & -4.672 & \\
Region & 1.240 & $0.52^{* *}$ \\
Appt. pres. & 1.118 & $0.26^{* * *}$ \\
Bookstore & 3.892 & $0.96^{* * *}$ \\
Individual & -1.885 & $0.56^{* * *}$ \\
Film & -1.408 & $0.49^{* *}$ \\
Prior & 1.592 & $0.58^{* * *}$ \\
Adult & 3.958 & $1.10^{* * *}$ \\
Magazine & -1.503 & $0.51^{* *}$ \\
Judge gender & -0.709 & 0.85 \\
\hline
\end{tabular}

$\%$ Categorized correctly $=86.2 \%$ (false positive $=20.0 \%$; false negative $=11.6 \%$ ).

Reduction in error $=53.2 \%$.

$-2 \times L L R=144.92$.

Model chi square $=109.93, \mathrm{df}=9, p<.0001$.

Number of cases $=210$, mean of dependent variable $=.295$.

${ }^{*}$ significant at $.05 ;{ }^{* *}$ significant at $.01 ;{ }^{* * *}$ significant at .001 .

When the model was re-run without the variable for gender, the percentage of votes categorized correctly and the reduction in error were precisely the same as before. Therefore, no gender-based differences appear to exist in the voting behavior of judges in obscenity cases.

The effect of judges' gender on votes in search and seizure cases is presented in table 2 . The model is statistically significant and successful in predicting almost $90.0 \%$ of the votes. In general, the results are consistent with Segal's (1984) findings for the Supreme Court. The case facts that had the biggest impact on the probability of a liberal vote were the existence of a search warrant, a finding of probable cause by the trial court, or a trial court finding that one or more generally recognized exceptions to the warrant requirement existed.

Once again, the addition of the gender of judges to the model has no discernible effect. The coefficient for gender is small and does not approach statistical significance. Moreover, when the model was re-run without a variable for the gender of the judges, there was no reduction in the predictive accuracy of the model. Thus, it appears that the gender of a judge is unrelated to voting behavior in search and seizure cases. ${ }^{15}$

${ }^{15}$ One initially troubling aspect of the model displayed in table 2 is that there appears to be very little reduction in error over the accuracy that could be obtained by predicting that every vote would be conservative. Thus, some caution is necessary when generalizing about gender effects from these results. The failure of the model to produce a reduction in error appears to be due to the extreme skew of the 
TABLE 2

Logit COEFFICIENTS FOR THE LIKELIHOOD OF A LIBERAL VOTE SEARCH AND SEIZURE CASES, 1981-1990

\begin{tabular}{lrl}
\hline Independent Variables & MLE & SE \\
\hline Intercept & -1.390 & \\
Region & -0.107 & 0.22 \\
Appt. pres. & 0.365 & $0.12^{* *}$ \\
Home & 0.162 & 0.25 \\
Business & 0.532 & 0.34 \\
Extent & 0.176 & 0.33 \\
ProbCaus & -0.571 & $0.24^{* *}$ \\
Warrant & -0.793 & $0.29^{* *}$ \\
Except & -0.953 & $0.21^{* * *}$ \\
Judge gender & -0.136 & 0.35 \\
\hline
\end{tabular}

$\%$ Categorized correctly $=89.4 \%$ (false positive $=10.6 \%$; false negative $=0.0 \%$ ).

Reduction in error $=0 \%$.

$-2 \times L L R=625.32$.

Model chi square $=45.21, d f=9, p<.0001$.

Number of cases $=994$, mean of dependent variable $=.105$.

${ }^{*}$ significant at $.05 ;{ }^{* *}$ significant at $.01 ;{ }^{* * *}$ significant at .001 .

The results of the test of the effects of gender on employment discrimination cases are displayed in table 3 . The model is successful in predicting $70.9 \%$ of the votes and produces a reduction in error of $40.7 \%$. As expected, presidential appointment effects are strong. Moreover, several case facts and litigant characteristics significantly affect the probability of a liberal vote.

Further examination of table 3 reveals that, in sharp contrast to the results in obscenity and search and seizure cases, the coefficient for gender is positive, robust, and statistically significant. Thus, it appears that the gender of the judge is strongly related to the probability of a liberal vote in job discrimination cases.

Having established that judges' gender has a statistically significant impact on their votes, we now ask, in probabilistic terms, what is the magnitude of this effect after the model has controlled for the effects of case facts, litigant characteristics, and presidential appointment? To answer this question, we computed the estimated probability of a liberal vote for male judges and for female judges using the

dependent variable ( $89 \%$ of the votes uphold the validity of the search). To provide at least a partial test of this hunch, we adopted the strategy utilized by Songer and Sheehan $(1992,249)$. We selected a new sample with a dependent variable that was not skewed by combining all of the liberal votes with a random $11 \%$ sample of the conservative votes. The model was then re-run on this new sample. The model for this new sample correctly predicted $66.7 \%$ of the votes and had a reduction in error of $32.3 \%$. Judge gender in this new model still had little impact (MLE $=-0.12$ ), was statistically insignificant, and increased neither the proportion of votes categorized correctly nor the reduction in error. 
TABLE 3

LOGIT COEFFICIENTS FOR THE LIKELIHOOD OF A LIBERAL VOTE JOB DisCRIMINATION CASES, 1981-1990

\begin{tabular}{lrl}
\hline Independent Variables & MLE & SE \\
\hline Intercept & -3.136 & \\
Region & 0.081 & 0.25 \\
Appt. pres. & 0.570 & $0.12^{* * * *}$ \\
Amicus & 2.539 & $0.65^{* * *}$ \\
Poor & -1.058 & $0.53^{*}$ \\
Govt defend & 2.328 & $0.71^{* * *}$ \\
Business & 2.423 & $0.70^{* * *}$ \\
RaceDis & 0.781 & $0.27^{* *}$ \\
Handicap & -1.335 & $0.55^{*}$ \\
SexDis & 1.714 & $0.38^{* * *}$ \\
PastDis & 2.601 & $0.84^{* *}$ \\
Evidence & 0.771 & $0.26^{* *}$ \\
Seniority & -2.405 & $0.90^{* *}$ \\
Prefer & 0.931 & 0.89 \\
Judge gender & 0.758 & $0.34^{*}$ \\
\hline
\end{tabular}

$\%$ Categorized correctly $=70.9 \%$ (false positive $=29.2 \%$; false negative $=29.0 \%$ ).

Reduction in error $=40.7 \%$.

$-2 \times L L R=453.24$.

Model chi square $=127.50, d f=16, p<.0001$.

Number of cases $=419$, mean of dependent variable $=.491$.

*significant at $.05 ;{ }^{* *}$ significant at $.01 ;{ }^{* * *}$ significant at .001 .

MLE coefficients for each of the other independent variables reported in table 3 together with the mean values of those variables. When the values of all the other independent variables are set at their mean, the probability that a male judge will cast a liberal vote is $38 \%$ while the estimated probability of a liberal vote by a female judge is $75 \%$. Thus, the impact of gender appears to be quite substantial.

Finally, we sought to determine whether the greater propensity of female judges to cast liberal votes was due to greater sympathy for the victims of gender discrimination (as expected by political activists) or whether it reflected a more general orientation toward equal protection. To obtain a rough answer to this question, we conducted two supplemental analyses. First, we re-ran the model described in table 3 for the subset of cases that did not raise any gender discrimination claims (e.g., race discrimination cases). The results suggest that gender-based differences among judges persist even in cases involving allegations of employment discrimination not related to sex. Overall, the model for nongender cases is very similar to that for the larger sample of all employment discrimination cases. The model predicts $71.8 \%$ of the votes correctly, with a reduction in error of $36.9 \%$, nearly identical to the results for the full sample of discrimination cases. More importantly, 
gender of the judge continued to be strongly related to judicial votes, with a coefficient of 0.692 , significant at the .051 level and only slightly smaller in magnitude than the coefficient for gender in the model for all discrimination cases.

As a second test of whether the greater liberalism of female judges was primarily due to sympathy for the victims of gender discrimination, we re-ran the model presented in table 3 with the addition of a multiplicative term for the interaction between gender of the judge and the variable "sex discrimination." In this revised model, both the gender of the judge and type of case (sex discrimination or other types of discrimination) remain statistically significant and of approximately the same magnitude as they were in the model presented in table $3 .{ }^{16}$ But the interaction between the two variables is very small ${ }^{17}$ and statistically insignificant. This suggests that whether the case involves gender discrimination or some other type of discrimination does not affect the greater propensity of female than male judges to cast a liberal vote.

\section{Discussion}

The results of our analysis of obscenity and search and seizure cases suggest that there are no differences in the voting behavior of male and female judges. In employment discrimination cases, however, our results were quite different. $\mathrm{Fe}$ male judges were more likely than their male colleagues to support the alleged victim of discrimination. In sum, our analysis indicates that the introduction of women judges to the federal appellate bench has had a substantial impact on decision making in employment discrimination cases but no measurable effect on search and seizure and obscenity cases. Clearly, the effect of gender on judicial behavior varies with the context of the decision-making process. This finding does not support the sets of hypotheses derived either from the expectations of the activists or from the earlier empirical analyses.

Among the alternative sets of hypotheses, only feminist legal theory recognizes that the behavior of women judges would not be confined to a single liberalconservative dimension across issue areas. Although the results did not completely support the theoretical expectations associated with feminist jurisprudence, the analysis suggests that women judges will speak in a "different voice" when dealing with claims of discrimination. It is possible that the socialization of women who attend law school and pursue legal careers that culminate in federal judicial appointments subverts tendencies to express concerns for relationships and community rather than autonomy and individual rights. But that socialization, effective as it may be in thoroughly grounding lawyers in established methods of legal reasoning, may not be strong enough to overcome the concern women have for people

\footnotetext{
${ }^{16}$ The MLE for gender of judge increases slightly to 0.783 , significant to the .05 level, while the MLE for sex discrimination increases to 1.903 , significant at .001 .

${ }^{17} \mathrm{MLE}=0.011$, standard error $=0.828$.
} 
who have been targets of discrimination when their claims raise the interdependent right to full membership in the community.

Alternatively, it is possible that women judges do not bring a distinct perspective to judging. If so, the differences we found in voting patterns between women and men in employment discrimination cases may simply be a result of women judges' identification with other victims of discrimination. Thus, women judges' support for claimants in employment discrimination cases may simply reflect a concern for protecting individual rights in an area of particular salience to them, rather than a concern for connection, context, and responsibility.

The results of our analysis should be interpreted with caution. This study was confined to three narrowly defined issue areas. Moreover, the need to control explicitly for case content led us to develop models that contain different variables associated with the specific policy areas. Nevertheless, the results of this study, and other empirical analyses, represent a starting point for research on women judges. Women judges in significant numbers are so new to the legal system that, although it is now possible to begin to study their decision making, it is not yet within our reach to assess the extent of their impact with certainty. In time, as more women assume positions on the federal courts and as the decisions of women who are currently serving continue to accumulate, further research that reaches firm conclusions will become feasible. Such research must include analysis of voting behavior and judicial reasoning as well as the career patterns and socialization of women judges.

Manuscript submitted 16 fune 1992

Final manuscript received 10 September 1993

\section{REFERENCES}

Aldrich, John H., and Forrest D. Nelson. 1984. Linear Probability, Logit and Probit Models. Sage.

Allen, David W., and Diane E. Wall. 1987. "The Behavior of Women State Supreme Court Justices: Are They Tokens or Outsiders?" The fustice System Fournal 12:232-44.

Allen, David W., and Diane E. Wall. 1990. "The Behavior of Women State Supreme Court Justices: An Update." Mississippi State University. Typescript.

Berkson, Larry, and Susan B. Carbon. 1980. The United States Circuit fudge Nominating Commission. Its Members, Procedures and Candidates. Chicago: American Judicature Society.

Binion, Gayle. 1991 "Toward a Feminist Regrounding of Constitutional Law." Social Science Quarterly 72:207-20.

Cohodas, Nadine. 1983. "Reagan's Judicial Selections Draw Differing Assessments." Congressional Quarterly January 15, 1983.

Constantini, Edmund, and Kenneth Craik. 1972. "Women as Politicians: The Social Background, Personality and Careers of Female Party Leaders." Fournal of Social Issues 28:217-36.

Cook, Beverly B. 1981. "Will Women Judges Make a Difference in Women's Legal Rights." In Women, Power E Political Systems, ed. M. Rendell. London: Croom Helm.

Cook, Beverly B. 1988. "Women as Judges." Women in the fudicial Process. Washington, DC: The American Political Science Association. 
Davis, Sue. 1986. "The Impact of President Carter's Judicial Selection Reforms: A Voting Analysis of the United States Courts of Appeals." American Politics Quarterly 14:320-44.

Davis, Sue. 1994. "Do Women Judges Speak 'In a Different Voice'? Carol Gilligan, Feminist Legal Theory, and the Ninth Circuit." Wisconsin Women's Law Fournal April: 7-8.

Dudley, Robert L. 1989. "State High Court Decision Making in Pornography Cases." Presented at the annual meeting of the American Political Science Association, Washington, DC.

Frankovic, Kathleen. 1977. "Sex and Voting in the U.S. House of Representatives." American Politics Quarterly 5:315-31.

Gehlen, Freida, 1977. "Women Members of Congress: A Distinctive Role." In A Portrait of Marginality, ed. Marianne Githens and Jewell Prestige. New York: McKay.

Gilligan, Carol. 1982. In a Different Voice: Psychological Theory and Women's Development. Cambridge, MA: Harvard University Press.

Goldman, Sheldon. 1979. "Should There Be Affirmative Action for the Judiciary?" Fudicature 62: 488-94.

Gottschall, Jon. 1983. "Carter's Judicial Appointments: The Influence of Affirmative Action and Merit Selection in Voting on the US Court of Appeals." fudicature 67:165-73.

Gruhl, John, Cassia Spohn, and Susan Welch. 1981. "Women as Policy Makers: The Case of Trial Judges." American Fournal of Political Science 25:308-22.

Gryski, Gerald S., Eleanor C. Main, and William J. Dixon. 1986. "Models of State High Court Decision Making in Sex Discrimination Cases." Fournal of Politics 48:143-55.

Hagle, Timothy M. 1989. "Constitutional Decision Making: The Obscenity Decisions of the Warren, Burger and Rehnquist Courts." Presented at the annual meeting of the American Political Science Association, Washington, DC.

Hagle, Timothy M. 1991. "But Do They Have to See it to Know It? The Supreme Court's Obscenity and Pornography Decisions." Western Political Quarterly 44:1039-54.

Howard, J. Woodford. 1981. Courts of Appeals in the Federal fudicial System: A Study of the Second, Fifth and District of Columbia Circuits. Princeton, NJ: Princeton University Press.

Karst, Kenneth L. 1984. "Woman's Constitution." Duke Law Fournal 1984:447-508.

Kritzer, Herbert M., and Thomas M. Uhlman. 1977. "Sisterhood in the Courtroom: Sex of Judge and Defendant in Criminal Case Disposition." Social Science Quarterly 14:77-88.

Leader, Shelah G. 1977. "The Policy Impact of Elected Women Officials." In The Impact of the Electoral Process, ed. Joseph Cooper and Louis Maisels. Beverly Hills: Sage.

Martin, Elaine. 1982. "Women on the Federal Bench: A Comparative Profile." fudicature 65:307-13.

Martin, Elaine. 1987. "Gender and Judicial Selection: A Comparison of the Reagan and Carter Administrations." Fudicature 71:136-42.

McGuire, Kevin T. 1990. "Obscenity, Libertarian Values, and Decision Making in the Supreme Court." American Politics Quarterly 18:47-67.

Segal, Jeffrey A. 1984. "Predicting Supreme Court Cases Probabilistically: The Search and Seizure Cases, 1962-1981." American Political Science Reviem 78:891-900.

Sherry, Suzanna. 1986. "Civic Virtue and the Feminine Voice in Constitutional Adjudication." Virginia Lam Reviem 72:543-615.

Songer, Donald R. 1988. "Nonpublication in the United States District Courts: Official Criteria Versus Inferences from Appellate Review. Fournal of Politics 50:206-15.

Songer, Donald R. 1990. "Criteria for Publication of Opinions in the U.S. Courts of Appeals: Formal Rules Versus Empirical Reality." Fudicature 73:307-13.

Songer, Donald R., and Sue Davis. 1990. "The Impact of Party and Region on Voting Decisions in the United States Courts of Appeals, 1955-1986." Western Political Quarterly 43:317.

Songer, Donald R., and Susan Haire. 1992. "Integrating Alternative Approaches to the Study of Judicial Voting: Obscenity Cases in the U.S. Courts of Appeals." American Fournal of Political Science 36:963-82.

Songer, Donald R., and Reginald S. Sheehan. 1992. "Who Wins on Appeal: Upperdogs and Underdogs in the United States Courts of Appeals." American Fournal of Political Science 36:235-58. 
Tate, C. Neal, and Roger Handberg. 1991. "Time Binding and Theory Building in Personal Attribute Models of Supreme Court Voting, 1916-1988." American fournal of Political Science 35:460-80.

Thomas, Sue. 1987. "The Effects of Race and Gender on Constituency Service." Presented at the annual meeting of the American Political Science Association, Chicago.

Thomas, Sue, and Susan Welch. 1991. "Women Legislators: Legislative Styles and Policy Priorities." Western Political Quarterly 44:445-56.

Thompson, Frank J. 1978. "Civil Servants and the Deprived: Sociopolitical and Occupational Explanations of Attitudes Towards Minority Hiring." American fournal of Political Science 22:325-47.

Walker, Thomas G., and Deborah J. Barrow. 1985. "The Diversification of the Federal Bench: Policy and Process Ramifications." Fournal of Politics 47:596-617.

Welch, Susan. 1985. "Are Women More Liberal Than Men in the U.S. Congress?" Legislative Studies Quarterly 10:125-34.

Wheeler, Stanton, Bliss Cartwright, Robert Kagan, and Lawrence Friedman. 1987. "Do the Haves Come Out Ahead? Winning and Losing in State Supreme Courts." Lam and Society Review $21: 403-45$.

Donald R. Songer is professor of political science, University of South Carolina, Columbia, SC 29208.

Sue Davis is associate professor of political science, University of Delaware, Newark, DE 19716.

Susan Haire is assistant professor of political science, University of North Carolina, Greensboro, NC 27412. 